\title{
Leprosy: Operational Indicators in a Brazilian Hyperendemic Municipality
}

\author{
Josiane Araújo Lima Costaํ, Olívia Dias de Araújo \\ Telma Maria Evangelista de Araújo ${ }^{3}$, \\ Andréia Rodrigues Mourada Costa Valle ${ }^{4}$, \\ Joelma Maria Costa ${ }^{5}$, Érica de Alencar Rodrigues Neri ${ }^{6}$, \\ Rosa Maria Duarte Veloso ${ }^{7}$
}

\section{Abstract}

Background: Interest in the subject arose from my participation in study groups and in a macro project on hanseniasis, in the city of Floriano by the Department of Nursing - Postgraduate Program. The city of Floriano is among the Piaui municipalities with the highest notified disease in the period of 2008 and 2009, with 187 cases being considered a municipality historically hyperendemic of leprosy thus emerged the following question: how to present the operational indicators of leprosy in city of Floriano? Faced with this situation, this research aims to: evaluate the operational indicators of leprosy in a city of Floriano, Piauí.

Methods: Descriptive study of time series with a quantitative approach, based on analysis of a population of 1,083 new cases of leprosy, for the period from 2001 to 2014. The data were collected in the database of Notifiable Diseases Information System. Data analysis was based on the parameters set out in Decree 149 of February 4, 2016 the Ministry of Health. We used Microsoft Excel 2013 program for data processing.

Resultados: during the study period were recorded 1072 cases of the disease. The indicators: proportion of new cases with degree of assessed disability and proportion of cured cases among new cases showed improvement in quality of care. The percentage of cases cured and evaluated in the discharge due to cure presented itself below the number of 1072. The evaluation of disability in high cure was $22.2 \%$ in $2007,98.8 \%$ in 2010 and $85.7 \%$ in 2014 and the
1 Degree in Nursing by Federal University of Piauí, Teresina, PI.

$2 \mathrm{PhD}$ in Nursing by Federal University of Piauí, Teresina, Pl, Brazil.

$3 \mathrm{PhD}$ in Nursing from the Federal University of Rio de Janeiro. School of Nursing Anna Nery, Brasil.Teresina, PI, Brasil. Brazil.

$4 \mathrm{PhD}$ in Science, Postgraduate Program in Fundamental Nursing by Ribeirão Preto College of Nursing USP, Brazil. Teresina, PI, Brazil.

5 Nurse Municipal Health Foundation of Teresina, PI, Brazil.

6 Nurse Municipal Health Foundation of Teresina and Master's degree in Nursing from the Federal University of Piauí, Brazil.

7 Biologist, Nursing graduate from higher education college Floriano-Faesf, PI, Brazil.

Contact information:

Josiane Araújo Lima Costa.

”- josylima-@hotmail.com 
average percentage of contacts was 39.5\%, ranging from $3.5 \%$ in 2005 to $82 \%$ by 2013 .

Conclusion: Although the operational indicators showed slight improvement in the quality of care for people with hanseniasis is still a serious public health problem in the city of Floriano

\section{Keywords}

Hanseniasis.; Public Health; Health Services Evaluation.

\section{Introduction}

Leprosy is an infectious disease caused by Mycobacterium leprae, which has affinity for skin and peripheral nerves and sometimes leads to physical and functional disability in patients. It is transmitted by direct contact with infectious patients without treatment, being considered a disease with high infectivity, but with low pathogenicity. [1].

It constitutes a serious public health problem, especially in developing countries like Brazil, because its occurrence becomes prevalent in regions of low socioeconomic and health conditions, noted in areas of great inequalities sociais. [2] Leprosy is still to be a major cause of disability, it is estimated that there are between one and two million people living with varying degrees of disability worldwide. [3].

According to the World Health Organization (WHO), 16 countries in the world notified a thousand or more cases of leprosy in 2009. Asia had the highest detection rate with 9.39 cases per 100,000 inhabitants, followed by the Americas with $4.58 \mathrm{ca}-$ ses per 100,000. Brazil is the second country with the highest number of cases of leprosy in 2011 registered about 34,000 new cases of the disease, fewer only to 127,000 cases in India, which has a population five times greater. $[4,5]$.

The Ministry of Health was committed to eliminating leprosy as a public health problem by 2015, ie to achieve less than 1 case per 10,000 population. In 2010, Brazil had 1.56 cases per 10,000 inhabitants, in the same year, detected 34,894 new cases of leprosy, corresponding to an overall detection rate of $18.2 / 100,000$. Although remain high, there was a reduction of $35.1 \%$ detection rate in the period 2001-2010. [6, 7].

In Piaui 62 municipalities are considered hyperendemic, despite the significant reduction of leprosy prevalence rate in the state, which in 2010 was 3.5 cases/10,000 inhabitants, the state demand intensified action to eliminate the disease. This is justified by the fact that municipalities, including Floriano, still have detection rates of most disease $10 / 100$ thousand inhabitants, a factor that indicates standard hyperendemicity. [8].

On account of the target set for the elimination of leprosy by 2015, indicators have been defined to be used primarily for leprosy, among these are the operational indicators that assess the quality of care in health to the person affected by leprosy services. Used as tools to aid and quality management, operational indicators are essential for monitoring and evaluation, because they lead to the final result of the actions proposed in strategic planning, as well as, support criticality of results, reflecting the reliability of information, contribute to the continuous improvement of business processes and compare the performance to set priorities.9Given these projections, this article aims to evaluate the operational indicators of leprosy in Floriano municipality from 2001 to 2014. 


\section{Methods}

This study is part of a macro project of the Graduate Program at the Federal University of Piauí Nursing entitled: "Integrahans - Piaui: integrated approach to clinical, epidemiological, operational and psychosocial aspects of leprosy in hyperendemic municipalities of Piaui." This is a descriptive study with a quantitative approach, on the operational indicators of Floriano municipality of leprosy which is located in the south mesoregion Piaui 248 km from Teresina, Piauí state capital. Register a geographical area of 3409.649 square kilometers, this vast territory, less than 30 square kilometers are occupied by urban settlement of the municipality. In 2010, the Brazilian Institute of Geography and Statistics (IBGE) estimated the city population in 58.803 inhabitants. [10].

From June to October 2015 it was held retrospective data collection of leprosy cases $(n=1072)$ living in Floriano municipality notified in the period 2001 to 2014 were evaluated information present in the official online database Information System of Aggravation Notification (SINAN), by the Department of Health of Piauí (Sesapi).

Six operational leprosy indicators were calculated (proportion of new leprosy cases with a degree of disability assessed at diagnosis, cure rate of leprosy among new cases diagnosed in the years of the cohorts; proportion of cases healed in the year with degree of physical disability assessed; proportion of examined among household contacts of registered new leprosy cases in the year; proportion of leprosy cases in treatment dropout among new cases diagnosed in the years of the cohorts; Proportion of cases of recurrence among cases reported in the year) using the following variables: assessment of the degree of disability at diagnosis, input mode, output mode, number of contacts recorded. Interpretation of the data was based on the evaluation of these indicators according to the parameters for the control of leprosy, defined by the Ministry of Health in 2016. [11] Descriptive analyzes of the data were carried out with the calculation of simple ab- solute and relative frequencies for the variables under study. For the organization of the tables and make the graphs we used Excel 2013.

Os Data provided information provided to obtain operational indicators to assess the quality of leprosy services based on the recommendations of the HM Decree $n^{\circ} 149$ of February 2016. This study complies with the ethical principles of Resolution 466/2012 of the National Health Council and the data were accessed in official databases, and approved by the Ethics Committee of the Federal University of Piauí, in the Report no 1.115.818.

\section{Results}

In the period 2001-2014, there were 1072 new cases of leprosy in Floriano-PI, verifying the lower rate in 2013 (37); and higher frequency in 2003 (109).

By evaluating the proportion of new cases detected throughout the series, and their ratio evaluated at diagnosis, the data revealed that the quality of care was good in every year of the series, except in 2014 when there was a reduction in ratio evaluation in the diagnosis (82\%). (Figure 1).

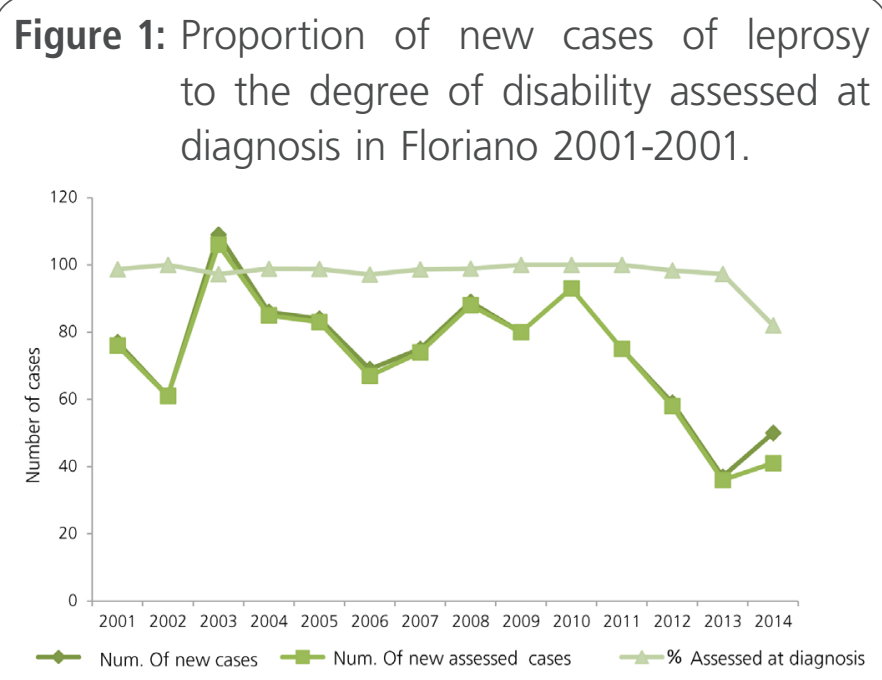

Source: SINAN/SVS-MS, 2015.

Regarding the care and monitoring of cases, the municipality has good healing indicators of cases diagnosed in the last 7 years of the cohort, reaching $96.3 \%$ in 2010. Nevertheless, it was observed 
that the proportion of cured cases is still below the number of diagnosed cases. In 2005 the situation was fair (76\%), but very close to the parameter considered poor by MS (> 75\%). (Figure 2).

As to the proportion of cases cured with this degree of disability, it is seen that in the early years of the series the situation was very poor, particularly in 2007 , when the percentage was only $22.2 \%$. From 2009 there was an increase in assessment, reaching 98.8\% in 2010 and $97.7 \%$ in 2011. But in the last three years the proportion of evaluated showed a downward trend, however it remained regular $(86,3 \%, 82,8 \%$ and $85,7 \%)$. (Figure 3).

Figure 2: Leprosy cure ratio among new cases diagnosed in the early cohort.

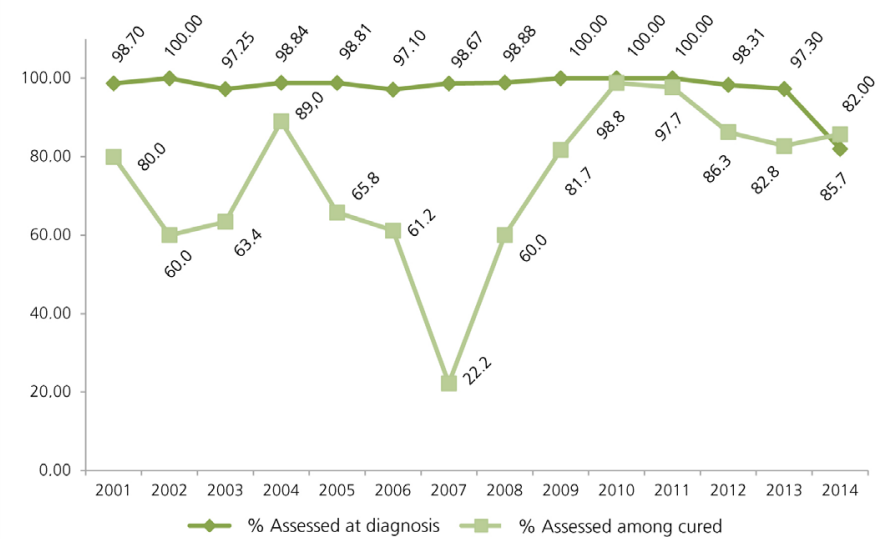

Source: SINAN/SVS-MS, 2015.

Figure 3: Proportion of cases healed in the year, degree of disability assessed.

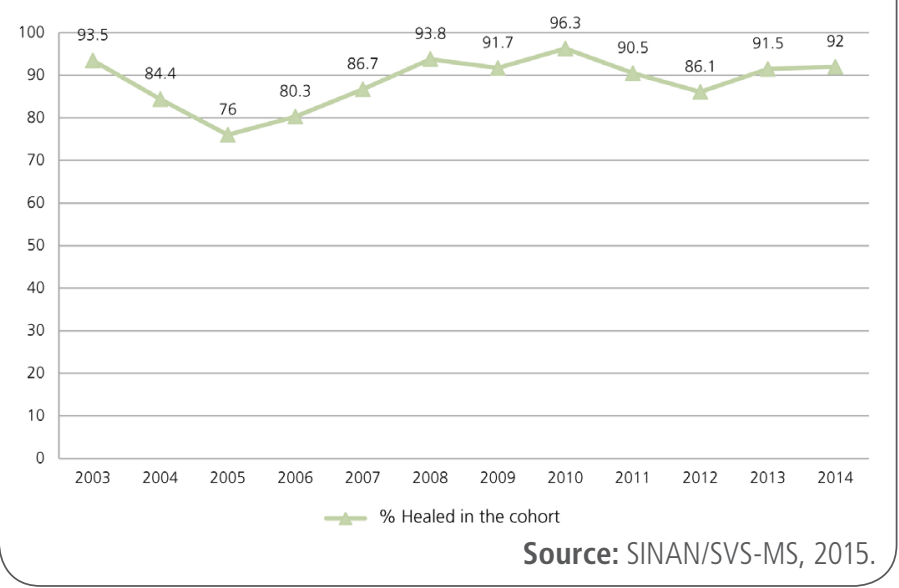

Figure 4: Proportion examined among household contacts recorded referring to new cases and proportion of cases in treatment dropout of leprosy among new cases diagnosed in the years of the cohorts in Floriano, Piauí.

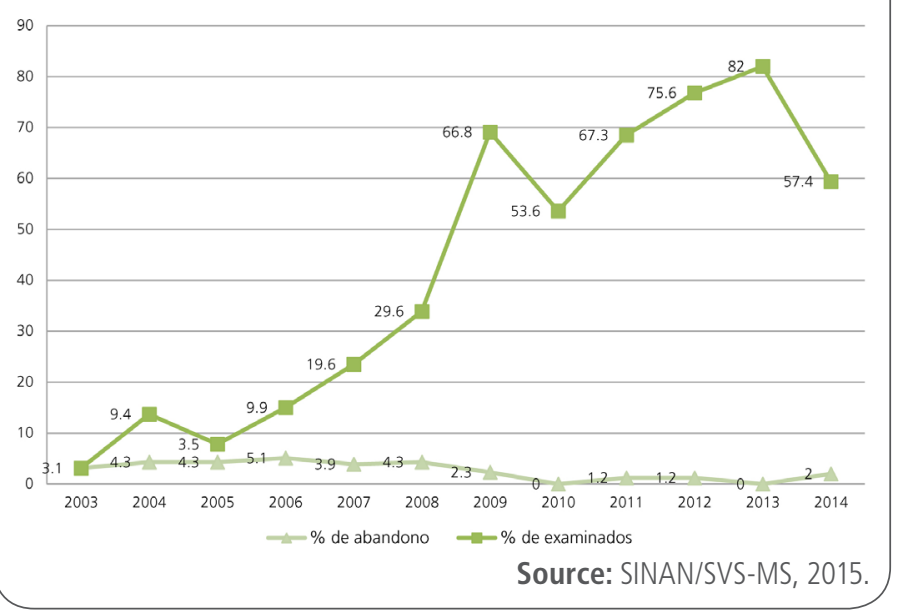

Figure 5: Proportion of cases of recurrence among cases reported in the year.

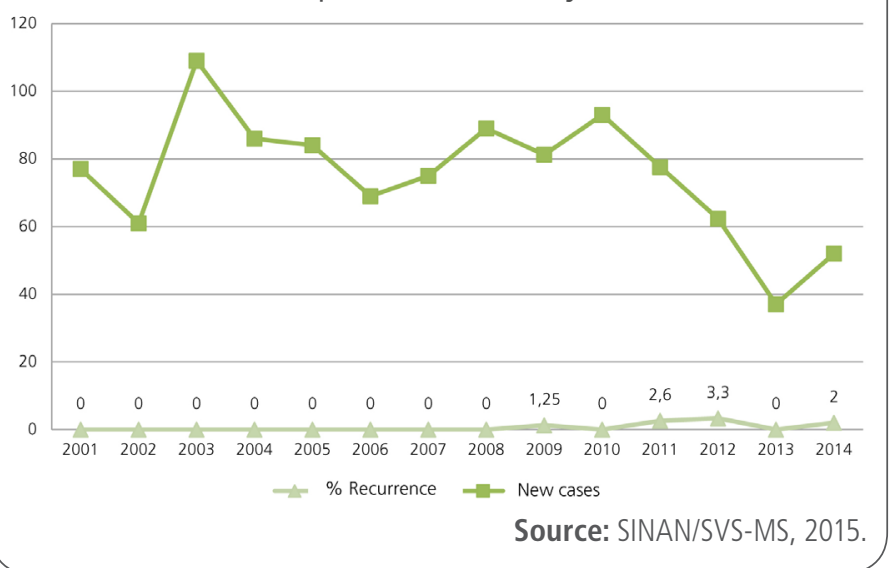

Figure 4 shows the proportion of abandonment and contacts examined over the years 2001-2014, in Floriano. It was found that the proportion of noncompliance was low, remaining classified as good throughout the series. The average percentage of contacts was $39.5 \%$, ranging from 3.5\% in 2005 to $82 \%$ in 2013. By 2008 the situation was presented as poor, from then on there was an increase going to the regular parameter, not coming throughout the series, to the parameter considered good by $\mathrm{MH}$. 
Have been reported throughout the series 6 cases of recurrence, and the highest proportion was $3.3 \%$ in 2012 . But one can not say that such data is high or not, since the ordinance does not provide a parameter to evaluate this indicator. (Figure 5).

\section{Discussion}

Despite great efforts to eliminate leprosy as a public health problem, it remains as a major problem that can lead to physical, emotional and socioeconomic consequences. The control strategy will continue to depend on early detection and treatment with multidrug therapy. [12].

As for the number of new cases of leprosy detected, a municipality can be classified according to the MS parameters: (a) hyperendemic - 40.00 cases/100,000 inhabitants or more; (B) very high 20.00 to 39.99 cases/100,000 inhabitants; (C) high - 10.00 to 19.99 cases/100,000 inhabitants; (D) average: 2.00 to 9.99 cases/100,000 inhabitants; (E) low - when less than 2.00 cases/100,000 inhabitants. Therefore, it is observed in Figure 1 that the city of Floriano, the rates remained high between the period 2001 and 2014 and is classified as hyperendemic, showing the continuity of transmission of the disease. [13].

During the study period the number of new cases detected showed up high (1083 cases) in view of the Ministry of Health's goal of achieving less than 1 case per 10,000 population. In order to monitor and control this endemic disease, operational indicators that assess the quality of care in health services were defined. Since the quality of leprosy services is an essential component of an effective program is based on the adequate training of professionals at every level, regular technical supervision and monitoring of key indicators. [14].

The analysis of the ratio of new cases of leprosy with the degree of disability evaluated in the diagnosis Floriano/PI is within the parameter considered good by $\mathrm{MH}$ (above 90\%). It is observed that there was a decrease in the evaluation of cases in 2014 inferring that there is need for greater attention by the municipal health services.

A similar study in Tocantins found that from 2001 to 2012, was recorded a total of 14,532 new cases of leprosy in residents. The magnitude and trend of leprosy described in the study period indicate that, in isolation, the municipalization of control measures, with full coverage for diagnosis and treatment by primary care is not enough to achieve the elimination goal. [15].

The actions of prevention of disabilities depend on the skills of health professionals to determine the diagnosis and guiding the appropriate treatment [16], since high degrees of disability favor the maintenance of Hansen's bacillus infection sources. [17].

The indicator cure rate among new cases diagnosed, useful to support the evaluation of the effectiveness of treatment, remained above $90 \%$ in the last seven years of the cohort, except in 2012, which showed $86.1 \%$, showing that monitoring of new cases diagnosed until the completeness of treatment is being held in Floriano. The recommended actions to cure and control of leprosy reinforce the importance of diagnosis and early treatment as early as possible. Regular care for patients with leprosy at the health facility or at home is essential to complete the treatment. [18].

The analysis of the indicator proportion of cases healed in the year with a degree of disability assessed points failure in the service offered by the city in the early years of the series (2002-2008), especially in 2007 , in which the percentage was only $22.2 \%$, inferring that the quality of care of health services in these years was not being effective, since the percentage of cases with a degree of disability assessed in healing always remained below the assessed at diagnosis. From 2009 there was an increase in assessment, reaching $98.8 \%$ in 2010 and $97.7 \%$ in 2011, but in the last three years of the series the proportion of assessed regressed, however was maintained regular (86.3\%, $82.8 \%$ and $85.7 \%)$. 
The results of this study are similar to those found in research conducted in Buriticupu, MA, in which it was concluded that, at the end of the treatment recommended by the Ministry of Health, most cases had not been evaluated. [19] This situation is also observed in the country as a whole, where the assessment of the degree of disability at diagnosis is approaching the $90 \%$ recommended by the Ministry of Health, with $89.3 \%$ of new cases of leprosy evaluated in 2009. In the last three years there was an increase of assessment at the time of healing, but still at a level well below the recommended and in 2009 , only $71.8 \%$ of cured patients were evaluated at discharge. [20].

Conduct that can prevent and even reverse physical consequences is the assessment of disability at the beginning of treatment, because if the patient has damaged nerves, the risk of developing disabilities is higher. Therefore, leprosy control programs must be discerning in initial and ongoing assessment of patients to prevent self-care through the resulting physical injury of disability. [21].

The investigation of contacts is an epidemiological surveillance action essential to early diagnosis and the breakdown of leprosy transmission chains and stands as a central strategy of the National Program for Leprosy Control. Considered all household contact and anyone who resides or has resided with leprosy patients [11]. This indicator was considered in the early years of the series as poor $(<50 \%)$, the average was $39.5 \%$, ranging from $3.5 \%$ in 2005 to $82 \%$ in 2013. By 2008 the situation was presented as precarious. Thereafter it was found that there was an increase in this proportion passing to the regulating parameter, but it was found that throughout the series indicator has not reached the parameter considered good by $\mathrm{MH}$. The performance of this indicator pointed to difficulties of services to conduct surveillance of household contacts for detection of new cases.

This finding is similar to Peixoto et. al [22] where leprosy program was classified as poor in São
Luís-MA. In a study held byCamello [23 it has been shown that the use of examination of household contacts of new cases detected and follow-up of household contacts of index cases, detected in the last 10 years, had a positive impact on the detection of new cases of the disease in Rio Grande do Sul.

Studies show that deficiencies in adherence to the exam contact take place mainly by the difficulty of finding them in the residence, change of municipality, denial of evaluation and death, pointing out that the best strategy is to encourage the examination of contacts for the education of patients, family and the community, since the lack of information about the disease and its modes of transmission puts the individual themselves as a liability on the disease control. [24] The decentralization of the actions places the teams of basic health units and family health as the main pillars to improve the quality of care and the actual control of endemic disease through the discovery of new cases by active detection with investigation of contacts, passive by spontaneous and referrals. [25].

Regarding the proportion of leprosy cases in treatment dropout in the city, it is observed that it remained within the standards established by the $\mathrm{MH}(<10 \%)$ for the entire cohort, notes a downward trend in the percentage of abandonment throughout the series, so that in the years 2010 and 2013 no case was registered.

he decree of the Ministry of Health No. 149 of February 2016, defines as a case of abandonment, all patients who failed to complete treatment within the maximum time allowed, despite repeated attempts to return and follow-up treatment. [11] Several factors can contribute effectively to the patient's withdrawal until then assisted by the disease control program, side effects of medications, lack of motivation, lack of knowledge about the disease, staff turnover, and no credibility in curing the disease. Abandonment of treatment implies a greater risk of transmission of bacilliferous cases detected and 
not treated properly, continuing the chain of transmission, increasing the risk of developing physical disabilities and deformities, and therefore the social stigma and discrimination against people affected and their families. [26].

It is defined as recurrence all cases of leprosy, regularly treated with standard official schemes and correctly indicated, discharged for healing and returning to present new clinical signs and symptoms of active infectious disease. Usually it occurs in more than five years after the cure. [11].

During the study period were reported 6 cases of recurrence, and the highest proportion was 3.3\% in 2012. This indicator identifies the notifiers municipalities of recurrence cases for monitoring of treatment failure, but can not be said that the data found they are high or not, since no parameter bring administrative rule specific for the assessment of the indicator.

\section{Conclusion}

Leprosy is still a serious public health problem in the city of Floriano. Although the municipality has shown some improvement in operating indicators, this is not the desired result for the control of the disease in the country.

When evaluating the operational indicators of Floriano was perceived a weakness of the agencies in implementing health surveillance actions on the illness and consequently the attention paid to the person with leprosy. The data show difficulties of services in carrying out evaluation of physical disabilities of cured cases and surveillance of household contacts for detection of new cases. Therefore, greater efforts are needed to achieve the desirable results of early detection and prevention of disabilities within the parameters defined by the Ministry of Health.

\section{References}

1. Pereira, E.V. E; Machado, H. A. S; Ramos, C. H. M; Nogueira, L.T; Lima, L. A. N. Perfil epidemiológico da hanseníase no município de Teresina, no período de 2001-2008. An Bras Dermatol. 2011.

2. Santos, L. A. C; Faria L.; Menezes, R.F. Contrapontos da história da hanseníase no Brasil: cenários de estigma e confinamento. Revista Brasileira de Estudos de População. São Paulo. v.25, n. 1, p. 167-190 . 2008

3. Yadav, N.; K, S.; Madke, B.; Dashatwar, D; Singh, N; Prasad, K.;Kesari,V. Leprosy elimination: A myth busted. J Neurosci Rural Pract. 2014.

4. Düppre, N. C. Risco de desenvolver hanseníase em contatos de pacientes, segundo positividade ao teste anti PGL-I e situação vacinal (BCG).Tese de doutorado.2008.

5. Imbiriba, E. N. B; Silva Neto, A. L; Souza, W.V. S; Pedrosa, V; Cunha, M.G; Garnelo, L. Desigualdade social, crescimento urbano e hanseníase em Manaus: abordagem espacial. Rev. Saúde Pública. São Paulo, v. 43, n. 4. 2009.

6. Ignotti, E; de Paula, R. C. Situação epidemiológica da hanseníase no Brasil: análise de indicadores selecionados no período de 2001 a 2010. In: Saúde Brasil 2010: Uma análise da situação de saúde e de evidências selecionadas de impacto de ações de vigilância em saúde. Ministério da Saúde. Secretaria de Vigilância em Saúde/MS, 2011.

7. Brasil. Ministério da Saúde. Secretaria de Vigilância em Saúde. Departamento de Vigilância em Doenças Transmissíveis. Plano integrado de ações estratégicas de eliminação da hanseníase, filariose, esquistossomose e oncocercose como problema de saúde pública, tracoma como causa de cegueira e controle das geohelmintíases: plano de ação 2011-2015. Brasília: 2011.

8. Brasil. Ministério da Saúde. Secretaria de Vigilância em Saúde. Sistema nacional de vigilância em saúde: relatório de situação: Piauí/Ministério da Saúde, Secretaria de Vigilância em Saúde. 5. Ed. - Brasília: Ministério da Saúde, 2011.

9. Brasil. Ministério da Saúde Secretaria de Gestão Estratégica e Participativa. Departamento de Articulação Inter federativa. Caderno de Diretrizes, Objetivos, Metas e Indicadores: 20132015. Brasília: Ministério da saúde, 2013

10. IBGE, Diretoria de Pesquisas, Coordenação de População e Indicadores Sociais. 2010.

11. Brasil. Ministério da Saúde. Secretaria de Vigilância em Saúde. Departamento de Vigilância das Doenças Transmissíveis. Diretrizes para vigilância, atenção e eliminação da Hanseníase como problema de saúde pública: manual técnico-operacional [recurso eletrônico]/Ministério da Saúde, Secretaria de Vigilância em Saúde, Departamento de Vigilância das Doenças Transmissíveis. - Brasília: Ministério da Saúde, 2016.

12. OMS, Organização mundial de Saúde. Estratégia global aprimorada para redução adicional da carga da hanseníase: 2011- 2015: diretrizes operacionais (atualizadas). Brasília: Organização Pan-Americana da Saúde, 2010 
13. Brasil. Ministério da Saúde. Secretaria de Vigilância em Saúde. Departamento de Vigilância Epidemiológica. Hanseníase no Brasil: dados e indicadores selecionados. Brasília, 2009.

14. OMS, Organização mundial de Saúde. Estratégia global aprimorada para redução adicional da carga da hanseníase: 2011- 2015: diretrizes operacionais (atualizadas). Brasília: Organização Pan-Americana da Saúde, 2010.

15. MONTEIRO, L. D. et al. Tendências da hanseníase no Tocantins, um estado hiperendêmico do Norte do Brasil, 2001-2012. Cad. Saúde Pública, Rio de Janeiro, 31(5): 971-980, mai, 2015.

16. Ministério da Saúde (BR). Secretária de Vigilância em Saúde. Departamento de Vigilância em Saúde. Manual de prevenção de incapacidades. $3^{\text {a }}$ ed. Brasília 2008.

17. Goulart, I. M.B; Dias, C.M; Oliveira, A.C. S; Silva, A.A; Alves, R.R; Quaresemin, C.R. Silva, D.P. Lopes, M.R.F. Faria G.A. Grau de Incapacidade: indicador de prevalência oculta e qualidade do programa de controle da hanseníase em um Centro de Saúde Escola no município de Uberlândia - MG Hansen. Int., v. 27, n.1, p.5-13, 2002.

18. Brasil. Ministério da Saúde. Secretaria de Políticas de Saúde. Departamento de Atenção Básica. Guia para o Controle da hanseníase. Brasília: Ministério da Saúde, 2002.

19. Aquino, C.M. D, Santos, S.J, Costa, L.M.J. Avaliação do programa de controle da hanseníase em um município hiperendêmico do Estado do Maranhão Brasil. Cad Saúde Pública, 2003.

20. Brasil. Ministério da Saúde. Secretaria de Vigilância em Saúde. Departamento de Vigilância Epidemiológica. Relatório de gestão da Coordenação Geral do Programa Nacional de Controle da Hanseníase - CGPNCH: janeiro de 2009 a dezembro de 2010/Ministério da Saúde, Secretaria de Vigilância em Saúde, Departamento de Vigilância Epidemiológica. - Brasília: Ministério da Saúde, 2011.

21. Finez, M. A; Salotti, S. R. A. Identificação do grau de incapacidades em pacientes portadores de hanseníase através da avaliação neurológica simplificada. J Health Sci Inst. 2011.

22. Vieira, C. S. C. A; Soares, M. T; Siqueira, C.T; Ribeiro, $X$; Silva, L.F. G. Avaliação e controle de contatos faltosos de doentes com Hanseníase. Rev. Bras. Enferm, Brasília 2008.
23. Dessuntii, E. M; Soubhia, Z.; Alves, E.; Aranda, C..M; Barro, M.P.A.A. Hanseníase: o controle dos contatos no município de Londrina-PR em um período de dez anos período de dez anos. Ver. Bras. Enferm, Brasília 2008.

24. Camello, R.S. Detecção de casos novos de hanseníase através do exame de contatos no estado do Rio Grande do Sul, Brasil. Hansen Int.2006.

25. Leite, K.K. C.; Costa, J.M.L.; Barral, A.; Caldas, A.J.M.; Corrêa, R.G.C.F.; Aquino, D.M.C. Perfil epidemiológico dos contatos de casos de hanseníase em área hiperendêmica na Amazônia do Maranhão. Cad. Saúde Colet. Rio de Janeiro. 2009.

26. Sousa, A. A. Adesão ao tratamento da hanseníase por pacientes acompanhados em unidades básicas de saúde de ImperatrizMA. S a $n$ a r e, Sobral, V.12, n.1, p. 06-12, jan./jun. - 2013.
Publish in International Archives of Medicine

International Archives of Medicine is an open access journal publishing articles encompassing all aspects of medical science and clinical practice. IAM is considered a megajournal with independent sections on all areas of medicine. IAM is a really international journal with authors and board members from all around the world. The journal is widely indexed and classified Q2 in category Medicine. 